University of Nebraska - Lincoln

DigitalCommons@University of Nebraska - Lincoln

Biological Systems Engineering: Papers and

Publications

Biological Systems Engineering

2002

\title{
Heat Curing of Soy Protein Films at Selected Temperatures and Pressures
}

\author{
Ki Myong Kim \\ University of Nebraska-Lincoln \\ Curtis Weller \\ University of Nebraska-Lincoln, cweller1@unl.edu \\ Milford Hanna \\ University of Nebraska-Lincoln, mhanna1@unl.edu \\ Aristippos Gennadios \\ Banner Pharmacaps Inc., aris.gennadios@catalent.com
}

Follow this and additional works at: https://digitalcommons.unl.edu/biosysengfacpub

Part of the Biological Engineering Commons

\begin{abstract}
Kim, Ki Myong; Weller, Curtis; Hanna, Milford; and Gennadios, Aristippos, "Heat Curing of Soy Protein Films at Selected Temperatures and Pressures" (2002). Biological Systems Engineering: Papers and Publications. 200.

https://digitalcommons.unl.edu/biosysengfacpub/200
\end{abstract}

This Article is brought to you for free and open access by the Biological Systems Engineering at DigitalCommons@University of Nebraska - Lincoln. It has been accepted for inclusion in Biological Systems Engineering: Papers and Publications by an authorized administrator of DigitalCommons@University of Nebraska Lincoln. 


\title{
Heat Curing of Soy Protein Films at Selected Temperatures and Pressures
}

\author{
Ki Myong Kim, Curtis L. Weller, Milford A. Hanna \\ Industrial Agricultural Products Center, University of Nebraska-Lincoln, 208 LW Chase Hall Lincoln, NE 68583-0730, USA \\ Aristippos Gennadios \\ Banner Pharmacaps Inc., 4125 Premier Drive, High Point, NC 27265-8144, USA \\ Corresponding author - C. L. Weller, tel 402 472-9337, fax 402 472-6338, email cweller1@unl.edu
}

\begin{abstract}
Vacuum and temperature effects on moisture content, water vapor permeability (WVP), color $(L, a, b$, and DE), tensile strength (TS), elongation (E), and total soluble matter (TSM) of soy protein isolate (SPI) films were examined. SPI films were cured at 60, 72.5 , or $85^{\circ} \mathrm{C}$ and at $101.3,81.32$, or $61.32 \mathrm{kPa}$ for $24 \mathrm{~h}$. As a result of heat-curing moisture content, WVP, E, and TSM decreased, and total color difference and TS increased. Pressure, individually and interactively with temperature, significantly affected film moisture content, TS, and TSM.
\end{abstract}

Keywords: soy protein, edible films, heat curing

\section{Introduction}

An edible film is defined as a free-standing, thin layer of edible material formed separate from a food product and placed on or between food components. Krochta and Mulder-Johnston (1997) classified film functions as inhibiting migration of components in food, carrying food ingredients, improving mechanical integrity of food, or improving handling characteristics of food. To fulfill such functions, films need to have specific barrier and mechanical properties.

Films produced from renewable biological materials provide opportunities for innovative uses in food protection and preservation. A few products have already found commercial use; such as collagen for casings (Hood, 1987), waxes for fruits and vegetables (Kaplan, 1986), and zein-based coatings for nutmeats and candies (Alikonis, 1979). There have been studies on production and properties of films made from several polysaccharide, protein, and lipid substances (Krochta \& MulderJohnston, 1997).

Proteins from several plant sources including soy, corn, wheat have been studied due to their film-forming capabilities. Soy protein films have poor moisture barrier properties due to the hydrophilic properties of soy proteins and the substantial amounts of hydrophilic plasticizer used in film preparation (Gennadios et al., 1994). In spite of this, there is considerable interest in edible and/or degradable soy films due to their environmentally friendly nature and their potential novel packaging uses in the food industry. Numerous studies have concentrated on improving mechanical and barrier properties of soy protein films through physical, chemical, or enzymatic treatments. Such studies included alkali treatments (Brandenburg et al., 1993); sodium alginate or propylene glycol alginate alkylation (Shih, 1994; Rhim et al., 1999); aldehydes cross-linking (Ghorpade, 1995; Rhein et al., 2000); UV irradiation (Gennadios et al., 1998; Rhim et al., 1999); and enzymatic cross-linking (Motoki et al., 1987; Stuchell \& Krochta, 1994; Yildirim \& Hettiarachchy, 1997).

Heat-treating protein films and coatings, or filmforming protein solutions, noticeably affected film properties. Cheftel and others (1985) reported thermal treatments of proteins at alkaline $\mathrm{pH}$ promoted formation of intra- and intermolecular cross-links. A variety of methods and substances have been employed to cure protein films by heating. The effects of heating on corn zein-epoxy resin (Howland, 1961; Howland \& Reiners, 1962), gelatin and fibrin protein films (Julius, 1967), peanut concentrate films (Jangchud \& Chinnan, 1999) and wheat gluten films (Kolster et al., 1992) have been reported.

Gennadios and others (1996) showed that it was possible to improve the moisture barrier properties of soy protein films by heat-curing. Pérez-Gago and others 
(1999) reported that heat-denatured whey protein films had higher tensile properties than native whey protein films. Studies showed that heat curing improved the mechanical toughness and moisture resistance of cast protein films made from corn zein (Julius, 1967), wheat gluten (Kolster et al., 1992; Ali et al., 1997), collagen (Weadock et al., 1984), whey protein (Miller et al., 1997), and soy protein (Gennadios et al., 1996; Rangavajhyala et al., 1997; Rhim et al., 2000). These results suggest that covalent cross-linking, caused by heat denaturation of protein, is responsible for film water insolubility and higher tensile properties.

Based on the results summarized above, it was postulated that heat treatment under vacuum would influence the curing process and further enhance the resulting film properties. Reduced pressure during curing should increase the rate of film drying compared to curing methods that use heat at atmospheric pressure. Level of cross-linking may be influenced by drying rate. Therefore, our objective was to determine the effects of pressure and temperature, during a 24-h heat-curing process, on film color, tensile strength, elongation at break, water vapor permeability, moisture content, and total soluble matter of cast soy protein isolate films.

\section{Materials and Methods}

\section{Film preparation}

Film-forming solutions were prepared by mixing $100 \mathrm{~mL}$ of distilled water, $5 \mathrm{~g}$ of SPI (Supro 620, Protein Technologies International, St. Louis, MO, USA), and $2.5 \mathrm{~g}$ of glycerin (U.S.P. food grade, Mallinckrodt, Paris, KY, USA). Sodium hydroxide ( $1 \mathrm{~mol} / \mathrm{L})$ was used to adjust the $\mathrm{pH}$ to $10.0 \pm 0.01$. After $\mathrm{pH}$ was adjusted, solutions were held for $15 \mathrm{~min}$ in a water bath at $75{ }^{\circ} \mathrm{C}$ and strained through cheesecloth (Cheesecloth Wipest, VWR Scientific Products, Chicago, IL, USA) to remove any bubbles and lumps (only minuscule amounts were present). The film-forming solutions $(90 \mathrm{~mL})$ were cast on flat, level Teflon ${ }^{\circledR}$-coated glass plates $(21 \mathrm{~cm} \times 35 \mathrm{~cm})$. Films were peeled from the plates after drying at ambient temperature for about $20 \mathrm{~h}$. Dried films were conditioned at $50 \% \mathrm{RH}$ and $25{ }^{\circ} \mathrm{C}$ for $24 \mathrm{~h}$. The conditioned films were then cured in a vacuum chamber (National Appliance Co. Portland, OR, USA) at $60 \pm 4,72.5 \pm 4$, or $85 \pm 4{ }^{\circ} \mathrm{C}$ under absolute pressures of 101.3 (atmospheric pressure), 81.32, or $61.32 \mathrm{kPa}$ for $24 \mathrm{~h}$. Pressures of 81.32 and $61.32 \mathrm{kPa}$ were reached after about 10 and $20 \mathrm{~min}$, respectively. After film curing, films were conditioned again at $50 \% \mathrm{RH}$ and $25^{\circ} \mathrm{C}$ for $48 \mathrm{~h}$ prior to testing.

\section{Moisture content}

Pieces (100-200 mg) of cured film were prepared by cutting. Cured film pieces were immediately weighed and dried for $24 \mathrm{~h}$ in an air-circulating oven at $105^{\circ} \mathrm{C}$ to determine moisture content (MC). Also, the $\mathrm{MC}$ values of cured films after being conditioned at $50 \% \mathrm{RH}$ and $25^{\circ} \mathrm{C}$ for $48 \mathrm{~h}$ were determined by drying film pieces (200-300 $\mathrm{mg}$ ) at $105{ }^{\circ} \mathrm{C}$ for $24 \mathrm{~h}$. MC values were determined, in triplicate, for each type of film as a percentage of initial film weight lost during drying and were reported on a wet weight basis (Ghorpade et al., 1995).

\section{Thickness}

Film thickness was measured to the nearest $2.54 \mu \mathrm{m}$ $(0.1 \mathrm{~mL})$ with a hand-held micrometer (B.C. Ames Co., Waltham, MA, USA). Five thickness measurements were taken on each water vapor permeability specimen, one at the center and four around the perimeter, and the mean was used in the water vapor permeability calculation. For tensile testing, five thickness measurements were taken along the length of each specimen and the mean was used in calculating film tensile strength.

\section{Color}

Color values of films were measured using a portable colorimeter (CR-300 Minolta Chroma Meter; Minolta Camera Co., Osaka, Japan). Film specimens were placed on a white plate, and the HunterLab color scale was used to measure color: $\mathrm{L}=0$ to 100 (black and white), $\mathrm{a}=-80$ to 100 (greenness and redness), and $\mathrm{b}=-80$ to 70 (blueness and yellowness). Standard values for the white calibration plate were $\mathrm{L}=96.86, \mathrm{a}=-0.07$, and $\mathrm{b}$ $=1.98$. The change of color was evaluated by comparing total color differences between films. Total color difference $(\Delta E)$ was calculated as:

$$
\begin{gathered}
\Delta E=\left[\left(\mathrm{L}_{\text {standard }}-\mathrm{L}_{\text {sample }}\right)^{2}+\left(\mathrm{a}_{\text {standard }}-\mathrm{a}_{\text {sample }}\right)^{2}\right. \\
\left.+\left(\mathrm{b}_{\text {standard }}-\mathrm{b}_{\text {sample }}\right)^{2}\right]^{1 / 2}
\end{gathered}
$$

\section{Tensile strength and percentage elongation at break}

Tensile strength (TS) and elongation at break (E) were both measured with an Instron Universal Testing Machine (Model 5566, Instron Corp., Canton, MA, USA) following the guidelines of ASTM Standard Method D 882-91 (ASTM, 1995a). Initial grip separation was set at $50 \mathrm{~mm}$ and cross-head speed was set at $500 \mathrm{~mm} / \mathrm{min}$. TS was expressed in $\mathrm{MPa}$ and calculated by dividing the maximum load $(\mathrm{N})$ by the initial crosssectional area $\left(\mathrm{m}^{2}\right)$ of the specimen. $E$ was calculated as the ratio of the final length of the point of sample rupture to the initial length of a specimen $(50 \mathrm{~mm})$, as a percentage. TS and $E$ tests for each type of film were replicated five times.

\section{Total soluble matter}

TSM was expressed as the percentage of film dry matter dissolved during immersion in distilled water for $24 \mathrm{~h}$. Measurement of TSM followed a modification of Rhim's method (Rhim et al., 2000). Film pieces $(20 \times 20$ $\mathrm{mm}^{2}$ ) were placed in $50-\mathrm{mL}$ beakers containing $30 \mathrm{~mL}$ of distilled water. Beakers were covered with Parafilm 'M' wrap (American National Can ${ }^{\mathrm{TM}}$, Chicago, IL, USA) and stored at $25{ }^{\circ} \mathrm{C}$ for $24 \mathrm{~h}$. After discarding the wa- 
ter remaining in the beakers after $24 \mathrm{~h}$, residual film pieces were rinsed gently with distilled water. Pieces were then dried in the air-circulating oven $\left(105^{\circ} \mathrm{C}\right)$ for $24 \mathrm{~h}$. The weight of dissolved dry matter was calculated by subtracting the weight of insoluble solid matter from the initial weight of solid matter.

\section{Water vapor permeability}

Five film specimens were tested for each type of film. WVP $\left(\mathrm{g} \mathrm{m} / \mathrm{m}^{2} \mathrm{~h} \mathrm{~Pa}\right)$ was calculated as

$$
\mathrm{WVP}=(\mathrm{WVTR} \cdot L) / \Delta p
$$

where WVTR was the measured water vapor transmission rate $\left(\mathrm{g} / \mathrm{m}^{2} \mathrm{~h}\right)$ through a film specimen, $L$ was the mean film specimen thickness $(m)$, and $\Delta p$ was the partial water vapor pressure difference $(\mathrm{Pa})$ between the two sides of the film specimen. WVTR was determined gravimetrically using a modification of ASTM Method E 96-95 (ASTM, 1995b) as described by Gennadios and others (Gennadios et al., 1998). Film specimens were mounted on polymethylmethacrylate cups filled with 16 $\mathrm{mL}$ of distilled water up to $1.03 \mathrm{~cm}$ from the film underside. Cups were placed in an environmental chamber set at $25^{\circ} \mathrm{C}$ and $50 \% \mathrm{RH}$. A fan was operated in the chamber moving the air with velocity of $196.3 \mathrm{~m} / \mathrm{min}$ over the surface of the films to remove the permeating water vapor. The weights of the cups were recorded six times at 1-h intervals. Linear regression was used to estimate the slope of this line in $\mathrm{g} / \mathrm{h}$.

\section{Statistical analysis}

The experimental design was a completely randomized design (CRD) of nine treatments ( 3 pressures $\times 3$ temperatures). An ANOVA table was generated for each tensile strength, percent elongation, water vapor permeability, and total soluble matter using the general linear model (GLM) procedure, a package program of the statistical analysis system (SAS Institute Inc., Cary, NC, USA). Significantly $(P<0.05)$ different means were separated with Duncan's multiple range test.

\section{Results and Discussion}

\section{Moisture content}

Temperature and pressure, individually and interactively, affected MC of SPI films after heat curing $(P<$ $0.05)$. Mean values of film MC significantly $(P<0.05)$ decreased from $16.6 \pm 2.3$ to $15.4 \pm 3.9$ to $14.3 \pm 1.5$ (g/100 g) for pressures of 101.3, 81.32, and $61.32 \mathrm{kPa}$, respectively. For temperatures of $60,72.5$, and $85^{\circ} \mathrm{C}$, mean MC values significantly decreased from $18.1 \pm 2.1$ to $15.4 \pm$ 1.3 to $12.9 \pm 2.2(\mathrm{~g} / 100 \mathrm{~g})$, respectively. The mean MC (wet basis) of unheated SPI films from a parallel study (Kim et al., 2001) after storage at $50 \% \mathrm{RH}$ and $25^{\circ} \mathrm{C}$ for $24 \mathrm{~h}$ was $27.06 \pm 2.04(\mathrm{~g} / 100 \mathrm{~g})$. As heating temperature increased and pressure decreased, film MC values significantly decreased $(P<0.05)$, as shown in Table 1 . The
Table 1. Moisture content (g/100 g) mean values of soy protein isolate films heat-cured for $24 \mathrm{~h}$ at select temperatures and pressures

\begin{tabular}{lccc}
\hline \multirow{2}{*}{$\begin{array}{l}\text { Pressure } \\
(\mathrm{kPa})\end{array}$} & $60{ }^{\circ} \mathrm{C}$ & $72.5^{\circ} \mathrm{C}$ & $85^{\circ} \mathrm{C}$ \\
\cline { 2 - 4 } 101.3 & $18.80 \pm 1.17 a$ & $19.84 \pm 1.02 a$ & $14.60 \pm 2.90 b c$ \\
82.32 & $15.70 \pm 0.69 b$ & $15.74 \pm 1.07 b$ & $14.74 \pm 0.98 b c$ \\
61.32 & $15.09 \pm 1.72 b c$ & $10.79 \pm 1.86 d$ & $12.82 \pm 0.24 c d$ \\
\hline
\end{tabular}

$a-d$ : Any two means followed by the same small-case letter are not significantly $(P>0.05)$ different by Duncan's multiple range test.

lowest MC $(10.79 \pm 1.86 \mathrm{~g} / 100 \mathrm{~g})$ was observed at the temperature and pressure combination of $72.5^{\circ} \mathrm{C}$ and $61.32 \mathrm{kPa}$, respectively. Heat-cured films did not absorb water up to the original MC of unheated films. This suggested the development of cross-links between hydrophilic sites along SPI protein chains, thereby decreasing protein access to water molecules. Heat treatment induces crosslinking of protein molecules (Cheftel et al., 1985) and the resulting structure restricts water uptake. Decreased water uptake was documented for propylene glycol alginate-treated SPI (Rhim et al., 1999) and for SPI films heat cured at atmospheric pressure (Gennadios et al., 1996).

\section{Color}

The total color difference $(\Delta E)$ of heat-cured films significantly increased with increasing curing temperature $(P$ $<0.05$ ) as shown in Figure 1. Heated films became more yellowish (higher positive $b$ values of $14.90 \pm 0.80,17.67$ \pm 0.91 , and $21.00 \pm 1.07$, respectively) as heating temperature increased. The DE of unheated SPI films of Kim and others (Kim et al., 2001) was $15.42 \pm 1.62$ and the mean $\mathrm{L}, \mathrm{a}$, and $\mathrm{b}$ color values were $89.13 \pm 0.53,-2.19 \pm$ 0.35 , and $15.15 \pm 1.67$, respectively. Increased film yellowness also was reported for heat-cured wheat gluten and SPI films (Gennadios et al., 1996; Rhim et al., 1999, 2000), and for protein reacted with the cross-linking agent dialdehyde starch (Rhim et al., 1998, 2000). Pressure and its interaction with temperature had no significant effects on $\Delta E$ of SPI films $(P>0.05)$.

\section{Water vapor permeability}

All heat-cured film samples had lower mean WVP values than the mean WVP of $9.32 \times 10^{-6} \mathrm{~g} \mathrm{~m} / \mathrm{m}^{2} \mathrm{hPa}( \pm$ $0.65 \times 10^{-6} \mathrm{~g} \mathrm{~m} / \mathrm{m}^{2} \mathrm{~h} \mathrm{~Pa}$ ) for the unheated SPI films of Kim and others (2001). WVP of cured films was significantly $(P<0.05)$ affected by temperature as shown in Figure 2. Thermal treatments of proteins apparently promoted formation of intra- and intermolecular crosslinks of amino acid residues (Cheftel et al., 1985). A significant $(P<0.05)$ reduction in film WVP (decreased to $6.55 \times 10^{-6} \mathrm{~g} \mathrm{~m} / \mathrm{m}^{2} \mathrm{hPa} \pm 0.61 \times 10^{-6} \mathrm{~g} \mathrm{~m} / \mathrm{m}^{2} \mathrm{~h} \mathrm{~Pa}$ ) was observed as heating temperature increased during film curing. The mean WVP value for films cured at $85^{\circ} \mathrm{C}$ for $24 \mathrm{~h}$ was similar to the result of Gennadios and oth- 


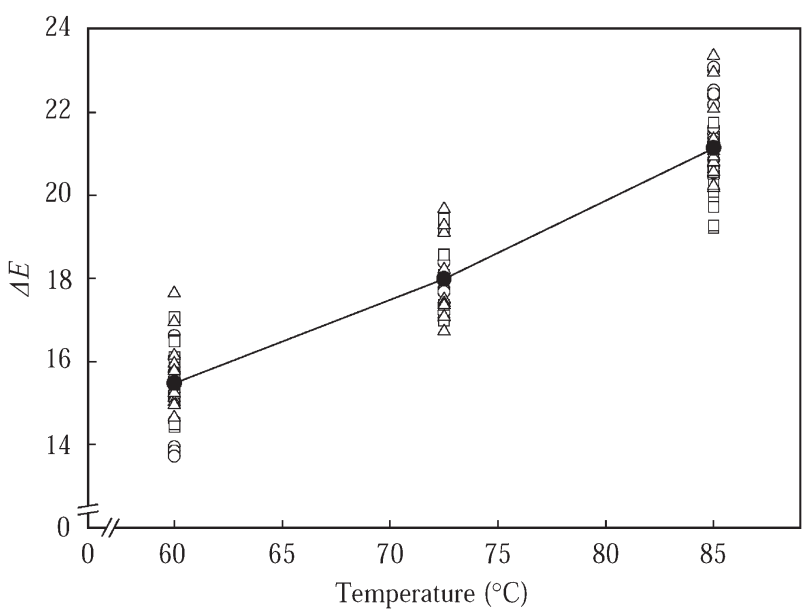

Figure 1. Total color differences of soy protein isolate films heatcured at pressures (abs.) of $101.32 \mathrm{kPa}(\circ), 81.32 \mathrm{kPa}(\square)$, or 61.32 $\mathrm{kPa}(\Delta)$ for $24 \mathrm{~h}$. The line through solid points $(\bullet)$ represents mean values of total color differences at each heating temperature.

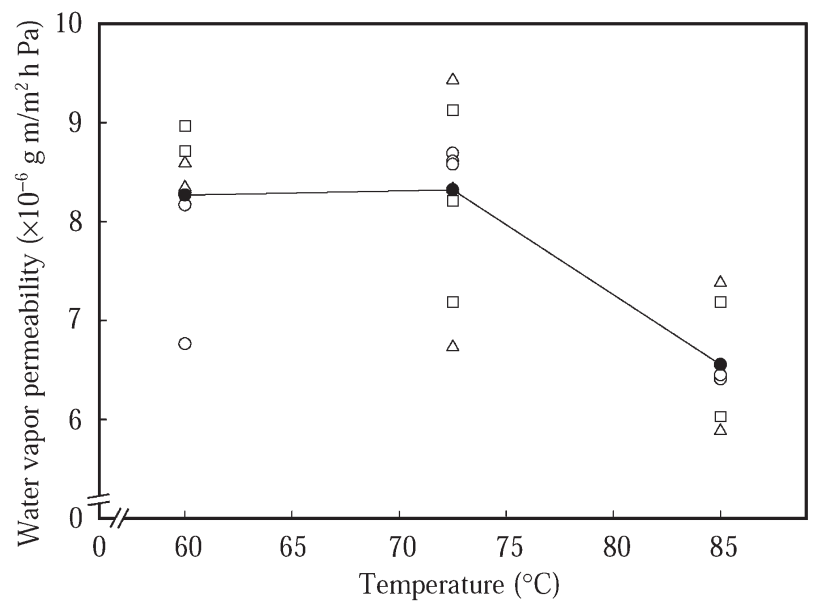

Figure 2. Water vapor permeability values $\left(10^{-6} \mathrm{gm} / \mathrm{m}^{2} \mathrm{~h} \mathrm{~Pa}\right)$ of soy protein isolate films heat-cured at pressures (abs.) of $101.32 \mathrm{kPa}(\circ), 81.32 \mathrm{kPa}(\square)$, or $61.32 \mathrm{kPa}(\Delta)$ for $24 \mathrm{~h}$. The line through solid points $(\bullet)$ represents mean values of water vapor permeability at each heating temperature.

ers (Gennadios et al., 1996). They reported that the WVP of SPI film heat-cured for $24 \mathrm{~h}$ at $80^{\circ} \mathrm{C}$ was $6.2 \times 10^{-6} \mathrm{~g}$ $\mathrm{m} / \mathrm{m}^{2} \mathrm{~h}$ Pa. Reducing the pressure during heat-curing did not affect the WVP of SPI film $(P>0.05)$. Gennadios and others (1996) suggested that the decrease in WVP of heated SPI films was attributable to formation of covalent links within the films and a decrease in protein hydrophilicity during heating.

\section{Tensile strength and elongation}

TS of heat-cured films increased significantly as curing temperature increased $(P<0.05)$. Pressure affected TS $(P=0.04)$ but there was no interactive effect of pressure and temperature $(P>0.05)$. SPI films heatcured at $85{ }^{\circ} \mathrm{C}$ had significantly higher tensile strength of $12.55 \mathrm{MPa}( \pm 1.67 \mathrm{MPa})$ than films heat-cured at 60 or $72.5^{\circ} \mathrm{C}$. Films heat-cured at 60 or $72.5^{\circ} \mathrm{C}$ were not significantly different from each other $(P>0.05)$. The mean

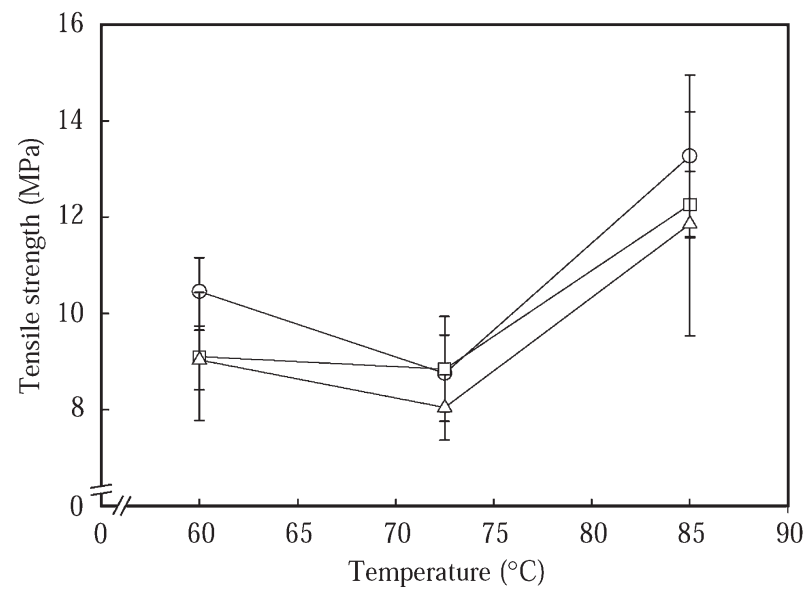

Figure 3. Tensile strength (MPa) of soy protein isolate films heat-cured at pressures (abs.) of $101.32 \mathrm{kPa}(\circ), 81.32 \mathrm{kPa}(\square)$, or $61.32 \mathrm{kPa}(\Delta)$ for $24 \mathrm{~h}$.

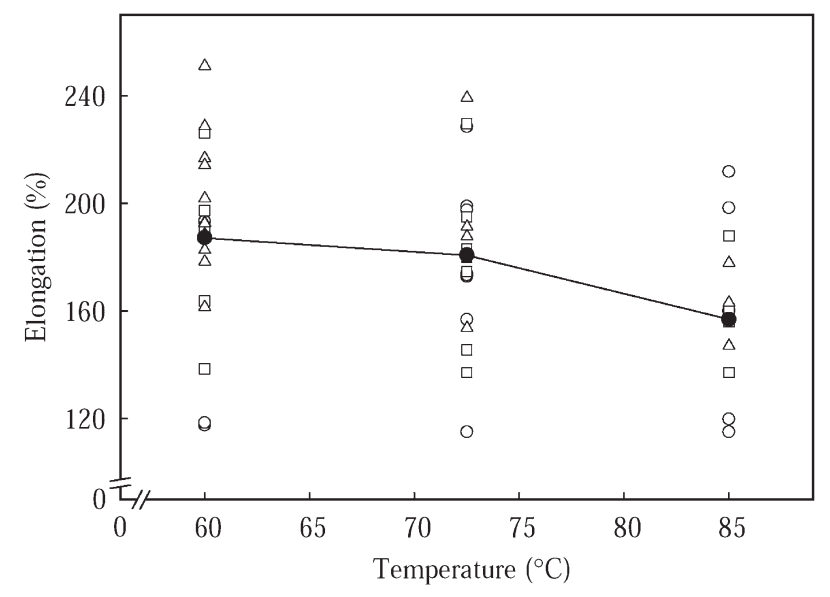

Figure 4. Elongation at break (\%) of soy protein isolate films heat-cured at pressures (abs.) of $101.32 \mathrm{kPa}(\circ), 81.32 \mathrm{kPa}$ (口), or $61.32 \mathrm{kPa}(\Delta)$ for $24 \mathrm{~h}$. The line through solid points $(\bullet)$ represents mean values of elongation (\%) at each heating temperature.

TS values for pressures of $101.3,81.32$, and $61.32 \mathrm{kPa}$ were $11.01 \pm 2.45,9.98 \pm 1.86$, and $9.57 \pm 2.03 \mathrm{MPa}$, respectively. Films cured at 81.32 or $61.32 \mathrm{kPa}$ were significantly $(P<0.05)$ different from those cured at $101.3 \mathrm{kPa}$, however, they were not significantly $(P>0.05)$ different from each other (Figure 3). The TS of unheated SPI films was $5.96 \mathrm{MPa}( \pm 1.10 \mathrm{MPa})$ from a parallel study (Kim et al., 2001). Heat treatment significantly $(P<0.05)$ decreased film $E$ (Figure 4). Temperature affected $E$ of SPI films significantly $(P<0.05)$. $E$ values of SPI films were $187.2 \%( \pm 34.53 \%), 180.8 \%( \pm 29.31 \%)$, and $156.9 \%$ $( \pm 24.89 \%)$ at temperatures of $60,72.5$, and $85^{\circ} \mathrm{C}$, respectively. Unheated SPI film had $E$ of $214.3 \%$ ( $\pm 31.29 \%$ ) (Kim et al., 2001). Pressure did not affect $E$ of SPI films during heat curing $(P>0.05)$. Gennadios and others (1996) reported decreases in $E$ as a result of heat treatment. They cured SPI films at 80 or $95^{\circ} \mathrm{C}$ at atmospheric pressure. $E$ values of films heated at $80^{\circ} \mathrm{C}$ for $24 \mathrm{~h}$ were 
not significantly $(P>0.05)$ different from $E$ values of films heated at $95{ }^{\circ} \mathrm{C}$ for $24 \mathrm{~h}$. All observed $E$ values were higher than those of about 30\% reported by Gennadios and others (1996). Their mean thickness values $(96.5 \pm 4.6 \mu \mathrm{m})$ were greater than those $(86.0 \pm 6.9 \mu \mathrm{m})$ of this study. The reason may have been that our curing chamber was a closed system with no air circulation.

Similar to the results of our study, increases in film TS and decreases in film $E$ also were observed for whey protein films heat-treated at 60,70 , or $80^{\circ} \mathrm{C}$ (Miller et al., 1997), wheat gluten films thermally-treated at 65,80 , or $95^{\circ} \mathrm{C}(25)$, and SPI films heat treated at 80,90 , or $95^{\circ} \mathrm{C}$ (Gennadios et al., 1996; Rhin et al., 2000). Miller and others (1997) reported that curing temperature and RH affected the rate of change of maximum TS, E, Young's modulus $\left(Y_{\mathrm{m}}\right)$, and WVP of whey protein films. Specifically, they reported that curing time linearly affected TS and $Y_{\mathrm{m}^{\prime}}$, while decreasing $E$ and WVP exponentially. The rate of exponential decay of $E$ increased with increasing RH. They also suggested that the moisture content of a film determined its mechanical properties.

\section{Total soluble matter}

Films or packaging materials should maintain moisture levels within the packaged product. Moisture should not move to the film or packaging material and dissolve it. Therefore, TSM of a film is important for food packaging applications. TSM was calculated as the percentage of soluble matter to initial dry matter in each film sample.

Temperature and pressure significantly affected the TSM values of SPI films $(P<0.05)$. There was no interactive effect of pressure and temperature $(P>0.05)$. TSM decreased to the lowest value of $15.56 \mathrm{~g} / 100 \mathrm{~g} \mathrm{( \pm}$ $1.64 \mathrm{~g} / 100 \mathrm{~g}$ ) at $85^{\circ} \mathrm{C}$ and $61.32 \mathrm{kPa}$. This was the lowest value across all curing temperatures and pressures. Though these results were calculated as soluble solids, Rhim and others (2000) reported that SPI film heatcured at $90{ }^{\circ} \mathrm{C}$ for $24 \mathrm{~h}$ had protein solubility of 0.03 $\mathrm{mg} / \mathrm{mL}$, which was only one-twelveth of the control $(0.36 \mathrm{mg} / \mathrm{mL})$. Heat-cured SPI films had lower TSM values than the value of $33.60 \mathrm{~g} / 100 \mathrm{~g}( \pm 3.65 \mathrm{~g} / 100 \mathrm{~g})$ for unheated SPI films (Table 2) from a parallel study (Kim et al., 2001).

Reductions in TSM of protein films following heat treatments have been reported (Gennadios et al., 1996; Rhim et al., 1998, 2000). Rhim and others (2000) reported that lower moisture content could have contributed to reduced protein solubility of heat-cured films because water adsorption and film swelling probably took longer than in the case of unheated films. Mean TSM value of heat-cured films were $22.50 \mathrm{~g} / 100 \mathrm{~g}( \pm 2.02 \mathrm{~g} / 100$ g), $17.32 \mathrm{~g} / 100 \mathrm{~g}( \pm 2.13 \mathrm{~g} / 100 \mathrm{~g})$, and $17.15 \mathrm{~g} / 100 \mathrm{~g}( \pm$ $2.04 \mathrm{~g} / 100 \mathrm{~g}$ ) at curing temperatures of $60,72.5$, and 85 ${ }^{\circ} \mathrm{C}$, respectively. Mean TSM values at a temperature of $60{ }^{\circ} \mathrm{C}$ were significantly $(P<0.05)$ different from mean TSM values at temperatures of 72.5 or $85^{\circ} \mathrm{C}$. Mean TSM values of $20.65 \mathrm{~g} / 100 \mathrm{~g}( \pm 3.64 \mathrm{~g} / 100 \mathrm{~g}), 18.85 \mathrm{~g} / 100 \mathrm{~g}$
Table 2. TSM (g/100 g) mean values of soy protein isolate films heat-cured for $24 \mathrm{~h}$ at select temperatures and pressures

\begin{tabular}{lccc}
\hline \multirow{2}{*}{$\begin{array}{l}\text { Pressure } \\
(\mathrm{kPa})\end{array}$} & \multicolumn{3}{c}{ Temperature } \\
\cline { 2 - 4 } & $60^{\circ} \mathrm{C}$ & $72.5^{\circ} \mathrm{C}$ & $85^{\circ} \mathrm{C}$ \\
\hline 101.3 & $24.62 \pm 2.16 a$ & $18.95 \pm 2.42 \mathrm{~cd}$ & $17.95 \pm 1.40 \mathrm{de}$ \\
82.32 & $20.98 \pm 0.80 b \mathrm{c}$ & $17.21 \pm 1.36 \mathrm{de}$ & $17.95 \pm 2.37 \mathrm{de}$ \\
61.32 & $22.09 \pm 1.33 a b$ & $16.17 \pm 2.00 \mathrm{de}$ & $15.56 \pm 1.64 \mathrm{e}$ \\
\hline
\end{tabular}

a-e: Any two means followed by the same small-case letter are not significantly $(P>0.05)$ different by Duncan's multiple range test.

$( \pm 2.28 \mathrm{~g} / 100 \mathrm{~g})$, and $18.54 \mathrm{~g} / 100 \mathrm{~g}( \pm 3.53 \mathrm{~g} / 100 \mathrm{~g})$ at pressures of $101.3,81.32$, and $61.32 \mathrm{kPa}$ were not significantly different $(P>0.05)$.

\section{Conclusions}

Properties of SPI films were determined after $24 \mathrm{~h}$ of heat-curing at reduced pressure and increased temperature. Film MC, TS, and TSM were affected significantly by temperature and pressure, individually. MC was also significantly affected by the interaction of temperature and pressure. Temperature, but not pressure, did significantly affect $\Delta E, \mathrm{WVP}$, and $E$ of SPI films. Low pressure and high temperature resulted in SPI films with high TS and low TSM. Heat-curing at elevated temperatures with vacuum was able to modify the protein matrix of edible protein-based films such as to strengthen their structure. The structural changes in treated films apparently do not physically or chemically restrict water diffusion compared to untreated films.

Acknowledgments - Journal Series No. 13266, Agricultural Research Division, Institute of Agriculture and Natural Resources, University of Nebraska-Lincoln. We acknowledge financial support from the Korea Science and Engineering Foundation.

\section{References}

Ali, Y., Ghorpade, V. M., and Hanna, M. A. Properties of thermally-treated wheat gluten films. Industrial Crops and Products, 6, 177-184 (1997)

Alikonis, J. J. Candy Technology. Westport, CT: The AVI Publishing Company, Inc. (1979)

ASTM. Standard test methods for tensile properties of thin plastic sheeting. In: Annual Book of ASTM Standards, vol. 8.01. West Conshohochen, PA: American Society for Testing and Materials, pp. 182-190 (1995a)

ASTM. Standard test methods for water vapor transmission of materials. In: Annual Book of ASTM Standards, vol. 4.06. West Conshohochen, PA: American Society for Testing and Materials, pp. 697-704 (1995b)

Brandenburg, A. H., Weller, C. L., and Testin, R. F. Edible films and coatings from soy protein. Journal of Food Science, 58, 1086-1089 (1993) 
Cheftel, J. C., Cug, J. L., and Lorrent, D. Amino acid, peptides, and proteins. In: O. R. Fennema, ed., Food Chemistry, 2nd edn., New York: Marcel Dekker, pp. 245-369 (1985)

Gennadios, A., Cezeirat, C., Weller, C. L., and Hanna, M. A. Emulsified soy protein-lipid films. In: D. J. Sessa and J. L. Willett, eds., Paradigm for Successful Utilization of Renewable Resources. Champaign, IL:AOCS Press, pp. 213-226 (1998)

Gennadios, A., Ghorpade, V. M., Weller, C. L., and Hanna, M. A. Heat curing of soy protein films. Transactions of the ASAE, 39, 575-579 (1996)

Gennadios, A., McHugh, T. H., Weller, C. L., and Krochta, J. M. Edible coatings and films based on proteins. In: J. M. Krochta, E. A. Baldwin, and M. Nisperos-Carriedo, eds., Edible Coatings and Films to Improve Food Quality. Lancaster, PA:Technomic Publishing, pp. 201-277 (1994)

Gennadios, A., Rhim, J. W., Handa, A., Weller, C. L., and Hanna, M. A. Ultraviolet radiation affects physical and molecular properties of soy protein films. Journal of Food Science, 63, 225-228 (1998)

Ghorpade, V. M., Gennadios, A., Hanna, M. A., and Weller, C. L. Soy protein isolate/poly(ethylene oxide) films. Cereal Chemistry, 72, 559-563 (1995)

Ghorpade, V. M., Li, H., Gennadios, A., and Hanna, M. A. Chemically modified soy protein films. Transactions of the ASAE, 38, 1805-1808 (1995)

Hood, L. L. Collagen in sausage casing. In: A. M. Pearson, T. R. Cutson, and A. T. Bailey, eds., Advances in Meat Research, vol. 4. New York: Van Nostrand Reinhold Company, pp. 109-129 (1987)

Howland, D. W. Curing prolamines. U.S. patent 3,010,917 (1961)

Howland, D. W., and Reiners, R. A. Preparation and properties of epoxy-cured zein coatings. Paint Varnish Products, 52, 31-34,38 (1962)

Jangchud, A., and Chinnan, M. S. Peanut protein film as affected by drying temperature and $\mathrm{pH}$ of film forming solution. Journal of Food Science, 64, 153-157 (1999)

Julius, A. Food wrapping membrane. U.S. patent 3,329,509 (1967)

Kaplan, H. J. Washing, waxing, and color-adding. In: W. F. Wardowski, S.Nagy, and W. Grierson, eds., Fresh Citrus Fruits. Westport, CT: The AVI Publishing Company, Inc., pp. 379-395 (1986)

Kim, K. M., Gennadios, A., Weller, C. L., and Hanna, M. A. Vacuum effect on soy protein films during heat curing treatment. Poster No.PO5-14 in Food Engineering and Rheology session 11th World Congress of Food Science and Technology. Seoul, Korea, 22-27 April (2001)

Kolster, P., Kuiper, H. J., and Vereijken, J. M. Non-food applications of wheat gluten. AACC Paper No. 68.172. Annual
Meeting of the American Association of Cereal Chemists. Minneapolis, MN, September 20-23, 1992

Krochta, J. M., and De Mulder-Johnston, C. Edible and biodegradable polymer films: Challenges and opportunities. Food Technology, 51, 61-74 (1997)

Miller, K. S., Chiang, M. T., and Krochta, J. M. Heat curing of whey protein films. Journal of Food Science, 62, 1189-1193 (1997)

Motoki, M., Nio, N., and Takinami, K. Functional properties of heterologous polymer prepared by transglutaminase between milk casein and soybean globulin. Agricultural and Biological Chemistry, 51, 237-239 (1987)

Pérez-Gago, M. B., Nadaud, P., and Krochta, J. M. Water vapor permeability, solubility, and tensile properties of heatdenatured versus native whey protein films. Journal of Food Science, 64, 1034-1037 (1999)

Rangavajhyala, N., Ghorpade, V. M., and Hanna, M. A. Solubility and molecular properties of heat-cured soy protein films. Journal of Agricultural Food Chemistry, 45, 4204-4208 (1997)

Rhim, J. W., Gennadios, A., Fu, D., Weller, C. L., and Hanna, M. A. Properties of ultraviolet irradiated protein films. Lebensmittel-Wissenschaft und-Technologie, 32, 129-133 (1999); doi: 10.1006/fstl.1998.0516

Rhim, J. W., Gennadios, A., Handa, A., Weller, C. L., and Hanna, M. A. Solubility, tensile, and color properties of modified soy protein isolate films. Journal of Agricultural Food Chemistry, 48, 4937-4941 (2000)

Rhim, J. W., Gennadios, A., Weller, C. L., Cezeirat, C., and Hanna, M. A. Soy protein isolate-dialdehyde starch films. Industrial Crops and Products, 8, 195-203 (1998)

Rhim, J. W., Wu, Y., Weller, C. L., and Schnepf, M. Physical characteristics of a composite film of soy protein isolate and propyleneglycol alginate. Journal of Food Science, 64, 149-152 (1999)

Shih, F. F. Interaction of soy isolate with polysaccharide and its effects on film properties. Journal of the American Oil Chemists' Society, 71, 1281-1285 (1994)

Stuchell, Y. M., and Krochta, J. M. Enzymatic treatments and thermal effects on edible soy protein films. Journal of Food Science, 59, 1332-1337 (1994)

Weadock, K., Olson, R. M., and Silver, F. H. Evaluation of collagen cross-linking techniques. Biomaterials, Medical Devices Artificial Organs, 11, 293-318 (1984)

Yildirim, M., and Hettiarachchy, N. S. Biopolymers produced by cross-linking soybean $11 S$ globulin with whey proteins using transglutaminase. Journal of Food Science, 62, 270-275 (1997) 